\title{
Publisher Correction: Immediate tool incorporation processes determine human motor planning with tools
}

\author{
G. Ganesh, T. Yoshioka, R. Osu \& T. Ikegami
}

Nature Communications 5:4524 doi: 10.1038/ncomms5524 (2014); Published online 31 Jul 2014; Updated 10 Apr 2018

The original HTML version of this Article had an incorrect article number of 4424; it should have been 4524 . This has now been corrected in the HTML; the PDF version of the Article was correct from the time of publication.

\footnotetext{
(c) (i) (-) Open Access This article is licensed under a Creative Commons Attribution-NonCommercial-ShareAlike 4.0 International License, which permits any noncommercial use, sharing, adaptation, distribution and reproduction in any medium or format, as long as you give appropriate credit to the original author(s) and the source, provide a link to the Creative Commons license, and indicate if changes were made. If you remix, transform, or build upon this article or a part thereof, you must distribute your contributions under the same license as the original. The images or other third party material in this article are included in the article's Creative Commons license, unless indicated otherwise in a credit line to the material. If material is not included in the article's Creative Commons license and your intended use is not permitted by statutory regulation or exceeds the permitted use, you will need to obtain permission directly from the copyright holder. To view a copy of this license, visit http://creativecommons.org/licenses/by-nc-sa/ $4.0 /$

(C) The Author(s) 2018
} 